\title{
Isolation and quantification of indicator and pathogenic microorganisms along with their drug resistance traits from bottled and jar water samples within Dhaka city, Bangladesh
}

\author{
Md. Aftab Uddin*, Mst. Aysha Siddiqua and Mst. Sadia Ahmed \\ Department of Microbiology, Stamford University Bangladesh, 51, Siddeswari Road, Dhaka-1217, Bangladesh
}

Received 09 May 2019/Accepted 20 July 2019

\begin{abstract}
Commercial drinking water may serve as potential threat to public health if these items are contaminated with a number of pathogenic microorganisms due to faulty manufacturing process. Present study attempted to isolate and quantify the microorganisms from various jar and bottle water samples collected from various areas of Dhaka city. Antibiotic susceptibility pattern of suspected bacterial isolates were also determined in this study. Out of the eighteen samples studied, ten were jar water samples and eight were bottled water samples. The range of total viable bacterial count (TVBC) in these samples ranged from $10^{2}$ to $10^{5} \mathrm{cfu} / \mathrm{ml}$. Specific pathogens such as, Salmonella spp., Shigella spp., Vibrio spp. and fecal coliforms could not be found in these samples. However coliforms could be detected in 10 samples. The antibiogram study showed that all Escherichia coli and Klebsiella spp. isolates found from these samples were sensitive against gentamicin $(10 \mu \mathrm{g})$ and azithromycin $(30 \mu \mathrm{g})$. Variable antibiotic resistance among these bacterial isolates was detected against cefotaxime ( $30 \mu \mathrm{g})$, streptomycin $(10 \mu \mathrm{g})$ and erythromycin $(15 \mu \mathrm{g})$.
\end{abstract}

Keywords: Isolate, Quantify, TVBC, Pathogens, Antibiogram.

\section{INTRODUCTION}

Safety and quality of water is always an important issue for healthy living even though many people do not have the access to clean and safe water for drinking and household uses $(1,2)$. Contamination of drinking water has been a common issue in developing countries like Bangladesh where sanitation and hygiene are not maintained. Such contamination of drinking water were reported to be associated with the spread of serious illnesses are mortality throughout the country $(2,3,4)$.

According to the findings of the World Health Organization (WHO), about 5 million people die each year because of the untreated water and practice of poor hygiene and $50 \%$ of the deaths are caused due to the cholera by itself. In Bangladesh, cholera, typhoid fever and bacillary dysentery are commonly reported diseases that are frequently transmitted through water that are also a major health concern. Pathogen likeEscherichia coli, Salmonella spp., Shigella spp., Bacillus spp., Pseudomonus spp., Streptococcus spp., Vibrio spp. etc. are the groups of bacteria which are responsible for causing disease like-diarrhea, enteric fever, dysentery, and other severe illness $(5,6)$. Due to our busy lifestyle people have to rely on readymade foods e.g. the road side foods and water. This type of jar water is more acceptable than those supplied by Water Supply and Sewerage Authority (WASA). Also it captures the market due to its cleanliness, purity and availability, so that people prefer to consume treated water instead of WASA water. Treated water ensures safety of infants and immunocompromised people who need to avoid the exposure to potential pathogens which are threat to human health (2). Due to these reasons, consumption of jar or bottled drinking water is increasing day by day in Bangladesh. It becomes a serious health issue when coliforms or fecal coliforms are identified in potable drinking water. This is why water borne diseases are frequently being reported by patients from various parts of Bangladesh (3).

A common problem regarding the medication inefficiency due to the rise of antibiotic resistances has recently gone far posing severe public health threats in the developing countries like Bangladesh. The reason behind such drug resistance has already been well known, especially due to the natural transfer of the drug-resistance genes along with the mass consumption of non-prescribed antibiotics $(7,8,9)$. Recently there has been a growing attention on the incidence of antibiotic-resistant bacteria (ARB) and antibiotic resistant genes (ARGs) in treated and untreated drinking water. ARB and ARGs create a public health concern when they convey antibiotic resistance (AR) to human pathogens (10). Therefore the purpose of the present study was to determine the microbiological quality of treated commercial drinking water samples collected from various locations in Dhaka city. The bacterial isolates were also examined to determine their resistances to the commonly recommended antibiotics in Dhaka. 


\section{MATERIALS AND METHODS}

Selection of study area \& collection of water samples for investigation The study was performed to understand the quality of processed drinking water samples in Microbiology Laboratory of Stamford University Bangladesh. A total of 10 jar water and 8 bottled water samples were collected from different locations of Dhaka city such as Mouchak, Shantinogor, Khilgaon, Baily road and Malibagh areas. The local people mainly use this water for drinking purposes. The samples were aseptically taken and transported to the laboratory as early as possible. After collecting the samples, within $24 \mathrm{~h}$ all the experiments were carried out (11).

Microbiological analysis \& Biochemical confirmation

Processing of the samples Serial dilutions of all the samples were made up to $10^{-1}$ with normal saline for microbiological analysis $(12,13)$.

Enumeration of total viable bacteria. The enumeration was performed by inoculating $0.1 \mathrm{ml}$ of each sample onto nutrient agar (NA) for the determination of total viable bacterial count (TVBC) by the spread plate technique. The plates were incubated at $37^{\circ} \mathrm{C}$ for $24 \mathrm{~h}$ for TVBC (2).

Estimation of total coliform and fecal coliform. A total of $100 \mathrm{ml}$ of sample was filtered and the filter paper was placed onto MacConkey agar an $\mathrm{mFC}$ agar for the detection of total coliform and fecal coliform, respectively. The plates were incubated at $37^{\circ} \mathrm{C}$ and $44.5^{\circ} \mathrm{C}$, respectively for $24 \mathrm{~h}(13)$

Number of cells per $\mathrm{ml}=$ number of colonies $\mathrm{x}$ dilution factor / volume of sample used (cfu/ml) (13)

Bacterial count. Plate count was restricted to 30-300 colonies and plates containing more than 300 colonies were designated as too numerous to count (TNTC) and plates containing fewer than 30 colonies were designated as too few to count (TFTC). The following formula was used for enumeration.

Biochemical tests for the confirmative identification. Finally, the standard biochemical tests were performed to confirm the identification of all the pathogenic isolates found in all types of bottle water and jar water samples by the previously described methods $(13,14)$.

Study of antibiogram. Pure culture of the bacteria isolated from various water samples were selected for assaying the antibiotic susceptibility pattern against different groups of antibiotics such as amikacin $(10 \mu \mathrm{g})$, streptomycin $(10 \mu \mathrm{g})$, gentamicin $(10 \mu \mathrm{g})$, cefotaxime $(30 \mu \mathrm{g})$, azithromycin $(30 \mu \mathrm{g})$ and erythromycin $(15 \mu \mathrm{g})$ by the Kirby-Bauer disc diffusion technique. First the isolates were grown on culture plate followed by transferring a small portion of a fresh colony to Muller-Hinton broth and incubating at $37^{\circ} \mathrm{C}$ for 4 to $5 \mathrm{~h}$ until the growth was found to the match turbidity standard of McFarland ( 0.5 standards). Muller- Hinton agar (MHA) plates were inoculated appropriately by spreading the culture by the help of sterile cotton swab. Discs (Oxoid, UK) were kept gently in equal space from each other using a sterile needle. Finally incubation of the MHA agar was done at $37^{\circ} \mathrm{C}$ for $18-24 \mathrm{~h}$ and zones of inhibition (if any) were calculated and the interpretation of the results were made as susceptible, intermediate and resistant $(15,16)$.

\section{RESULTS}

At present, there is inadequate information on the microbiological quality of commercially available potable water sample. It is important that the consumers need to be assured of their quality and safety. The transmission of water borne diseases is still a matter of major concern, despite worldwide efforts and modern technologies are being utilized for the production of safe drinking water $(2,3,7,17)$. Various types of health related problems are associated with the proliferation of etiological agents $(18,19)$. Along these lines, the present study portrays the isolation and quantification of indicator and some common pathogenic microorganisms from the jar water samples along with their drug resistance traits consumed in Dhaka, Bangladesh.

Prevalence of pathogenic microorganisms. The result of microbiological analysis performed on samples of jar and bottled water collected from the domestic markets of Dhaka city, Bangladesh appears in Table 1. Total viable bacterial count (TVBC) in all the samples observed in this study ranged from $10^{2}$ to $10^{5} \mathrm{cfu} / \mathrm{ml}$ (Table: 1). Potable water should be free from any bacteria that pose a health risk. The presence of heterotrophic plate counts (HPC) more than 500 $\mathrm{cfu} / \mathrm{ml}$ and coliforms play a main role in the detection of potential pathogens in drinking water. It can be considered as one of the notable parameters to control the quality of water for human consumption (3). In this study, two third of the samples including both the jar and bottle water samples failed to meet the HPC guideline, indicating a need for regular monitoring of these water samples by the concerned regulatory authorities.

Table 1. Load of various microorganisms in the bottle and jar water samples

\begin{tabular}{ccc}
\hline Sample No. & $\begin{array}{c}\text { TVBC } \\
(\mathrm{cfu} / \mathrm{ml})\end{array}$ & TCC \\
\hline Jar water 1 & $5.4 \times 10^{3}$ & Present \\
Jar Water 2 & $1.1 \times 10^{3}$ & Present \\
Jar Water 3 & $1.4 \times 10^{3}$ & Present \\
Jar Water 4 & $2.3 \times 10^{3}$ & Present \\
Jar Water 5 & $4.0 \times 10^{2}$ & Present \\
Jar Water 6 & $1.5 \times 10^{3}$ & Present \\
Jar Water 7 & $1.2 \times 10^{3}$ & Present \\
Jar Water 8 & $1.38 \times 10^{3}$ & Present \\
Jar Water 9 & $1.86 \times 10^{3}$ & Present \\
Jar Water 10 & $1.5 \times 10^{2}$ & Present \\
Bottle water 1 & $1.6 \times 10^{2}$ & Absent \\
Bottle water 2 & $2.6 \times 10^{2}$ & Absent \\
Bottle water 3 & $3.0 \times 10^{4}$ & Absent \\
Bottle water 4 & $2.25 \times 10^{3}$ & Absent \\
Bottled water 5 & $3.0 \times 10^{2}$ & Absent \\
Bottled water 6 & $<1.0$ & Absent \\
Bottled water 7 & $1.0 \times 10^{5}$ & Absent \\
Bottled water 8 & $2.0 \times 10^{5}$ & Absent \\
\hline
\end{tabular}

Traditionally Escherichia coli and Klebsiella spp. are used as indicator bacteria for detecting the water quality. As per the World Health Organization (20) and Bangladesh Drinking Water Standard (BDWS), the count of fecal coliform (FC) and total coliform (TC) should be 0 per $100 \mathrm{ml}$. The present study showed the presence of total coliforms in ten out of eighteen commercially treated water samples (Table 1). All the isolates were presumptively identified through various types of standard biochemical tests (Table 2).

Frequency of antibiotic resistant isolates. E. coli was found to be completely resistant against erythromycin and sensitive to azithromycin and gentamicin. On the contrary, $50 \%$ of the Klebsiella spp. showed resistant against erythromycin while rest of the antibiotics such as azithromycin, streptomycin, amikacin, gentamicin and cefotaxime were found to be effective (Table 3). Antimicrobial resistance (AMR) is the ability of microorganisms causing disease to withstand attacks by administration of antimicrobial medicine. Such drug resistance problem is one of the most common emerging problems in medical science. All isolates found in this study showed some degree of resistance towards some commonly available antibiotics. Antibiotic resistance can arise due to genetic modification or 
Tables 2. Biochemical tests for the isolated bacteria

\begin{tabular}{|c|c|c|c|c|c|c|c|c|c|c|}
\hline Assumed & & TSI & & $\mathrm{H}_{2} \mathrm{~S}$ & Indole & MR & $\mathbf{V P}$ & Citrate & Motility & Oxidase \\
\hline Organism & Slant & Butt & Gas & reaction & test & Test & Test & Test & Motinty & Test \\
\hline E. coli & $\bar{R}$ & $\bar{R}$ & - & + & + & - & - & - & + & - \\
\hline Klebsiella spp. & $\mathrm{Y}$ & Y & + & - & - & - & + & + & - & + \\
\hline
\end{tabular}

TSI = Triple Sugar Iron Test, Y = Yellow (Acid), R = Red (Alkaline), MR = Methyl Red, VP = Voges-Proskauer

Tables 2. Antibiogram profile of the bacterial isolates.

\begin{tabular}{cccccc}
\hline Name of & & \multicolumn{2}{c}{ Suspected Microorganisms } \\
\cline { 3 - 6 } Antibiotic & Disc & \multicolumn{2}{c}{ E. coli } & \multicolumn{2}{c}{ Klebsiella spp. } \\
disc & Content & \multicolumn{2}{c}{$\boldsymbol{N}=\mathbf{8}$} & \multicolumn{2}{c}{$\boldsymbol{N}=\mathbf{6}$} \\
& & $\boldsymbol{R} \%$ & $\mathbf{S \%}$ & $\boldsymbol{R} \%$ & $\mathbf{S \%}$ \\
Azithromycin & $30 \mu \mathrm{g}$ & $0 \%$ & $100 \%$ & $0 \%$ & $100 \%$ \\
Streptomycin & $10 \mu \mathrm{g}$ & $50 \%$ & $50 \%$ & $0 \%$ & $100 \%$ \\
Amikacin & $10 \mu \mathrm{g}$ & $50 \%$ & $50 \%$ & $0 \%$ & $100 \%$ \\
Gentamicin & $10 \mu \mathrm{g}$ & $0 \%$ & $100 \%$ & $0 \%$ & $100 \%$ \\
Erythromycin & $15 \mu \mathrm{g}$ & $100 \%$ & $0 \%$ & $50 \%$ & $50 \%$ \\
Cefotaxime & $30 \mu \mathrm{g}$ & $50 \%$ & $50 \%$ & $0 \%$ & $100 \%$ \\
\hline
\end{tabular}

$\mathrm{S}=$ Sensitive $; \mathrm{R}=$ Resistant (All the experiments have been done three times and the results were reproducible. One representative data has been shown).

adaptation to environmental changes. Mutation in bacterial genome can be transmitted to offspring and can help dissemination of drug resistance in bacterial population (21).

\section{CONCLUDING REMARKS}

It can be concluded that the presence of indicator microorganisms with an alarming total viable bacterial load in a number of commercial drinking water samples is a matter of great concern for the consumers. The microorganisms present in these samples showed some degree of resistance against some of the commonly prescribed antibiotics which are of significance from the view point of public health. Every possible measure should be taken by different regulatory bodies to ensure the safe consumption of such types of drinking water.

\section{ACKNOWLEDGEMENTS}

Authors would like to express their heartfelt gratitude to the Department of Microbiology, Stamford University Bangladesh for all the technical help. Besides authors also acknowledge the research groups whose findings have been used to complete this article.

\section{REFERENCES}

1. Khaniki GRJ, Zarei A, Kamkar A, Fazlzadehdavil M and Marei A. 2010. Bacteriological evaluation of bottled water from domestic brands in Tehran markets, Iran World Appl. Sci. J. 8:274-8.

2. Acharjee M, Rahman F, Jahan F and Noor R. 2013. Bacterial proliferation in municipal water supplied in Mirpur locality of Dhaka city, Bangladesh. CLEAN- Soil, Air, Water. 2:434-441

3. Majumder AK, Islam N, Nite RN and Noor R. 2011. Evaluation of microbiological quality of commercially available bottled water in the city of Dhaka, Bangladesh. S. J. Microbiol. 1: 24-30.

4. Uddin MA. 2018. Microbiological analysis of ready to eat foods collected from different places of Dhaka city, Bangladesh. S. J. Microbiol. 8: 30-33.

5. Munshi SK, Rahman MM and Noor R. 2012. Detection of virulence potential of diarrheagenic Escherichia coli isolated from surface water of rivers surrounding Dhaka city. J. Bang. Acad. Sci. 36:109-121.

6. Venkatesan KD, Balaji M and Victor K. 2014. Microbiological analysis of packaged drinking water sold in Chennai. Int. J. Med. Sci. Public Health. 3: 472-76.

7. Ahmed T, Baidya S, Sharma BC, Malek M, Das KK, Acharjee M, Munshi SK and Noor R. 2013. Identification of drug-resistant bacteria among export quality shrimp samples in Bangladesh. Asian J. Microbiol. Biotech. Env. Sci. 15:31-36.

8. Afroz H, Sultana F, Fakruddin M, Kamrunnahar, Khan ZUM and Datta S. 2013. Isolation of Escherichia coli and Staphylocccus aureus from full cream power milk sold under market conditions at Dhaka, Bangladesh and their antibiotic susceptibility. J. Adv. Sci. Res. 4:27-31.

9. Mamun SA, Das KK and Uddin MA. 2016. Microbiological analysis and determination of antibacterial activity of apple samples collected from local markets in Dhaka city, Bangladesh. S. J. Microbiol. 6:11-15.

10. Sanganyado E and Gwenzi W. 2019. Antibiotic resistance in drinking water systems: Occurrence, removal, and human health risks. Sci. Total Environ. 669:785-797.

11. American Public Health Association (AHPA). 1998. Standard methods for the examination of water and wastewater. Washington, D.C: American Public Health Association.

12. Jamal JB, Akter S and Uddin MA. 2018. Microbiological quality determination of pasteurized, UHT and flavoured milk sold in Dhaka, Bangladesh. S. J. Microbiol. 8:1-6.

13. Cappuccino JG and Sherman N. 1996. Microbiology - A Laboratory Manual. The Benjamin/Cummings Publishing Co., Inc., Menlo Park, California.

14. Alfrad EB. 2007. Bensons Microbiological Applications. Mcgraw-Hill Book Company, New York.

15. Bauer A, Kirby JC and Sheriss M. 1966. Antibiotic susceptibility testing by standardized single disc method. Am. J. Clinical pathol. 45:493-496.

16. Afroz H, Ahmed T and Uddin MA. 2015. Microbiological analysis and antibacterial activity of pear samples. S. J. Microbiol. 5:1-4.

17. Samuel O, Florence N and Ifeanyi O. 2106. Microbial Quality Assessment of Commercial Bottled Water Brands in Major Markets in Awka. Nigeria. Univers. J. Microbiol. Res.4:1-5.

18. Gangil R, Tripathi R, Patyal A, Dutta P and Mathur KN. 2013. Bacteriological evaluation of packaged bottled water sold at Jaipur city and its public health significance. Vet World. 6:27-30.

19 Butt AA, Aldridge KE and Sanders CV. 2004. Infections related to the ingestion of seafood part 1: viral and bacterial infections. Lancet Infect. Dis. 4:201-212.

20. FAO/WHO. 2003. Diet, nutrition and the prevention of chronic diseases. Report of a joint FAO/WHO. Expert Consultation. WHO Technical Report Series 916. Geneva. World Health Organization.

21. Sharma D and Malik A. 2012.Incidence and prevalence of antimicrobial resistant Vibrio cholerae from dairy farms. Afr. J. Microbiol. Res. 6:5331-5334. 